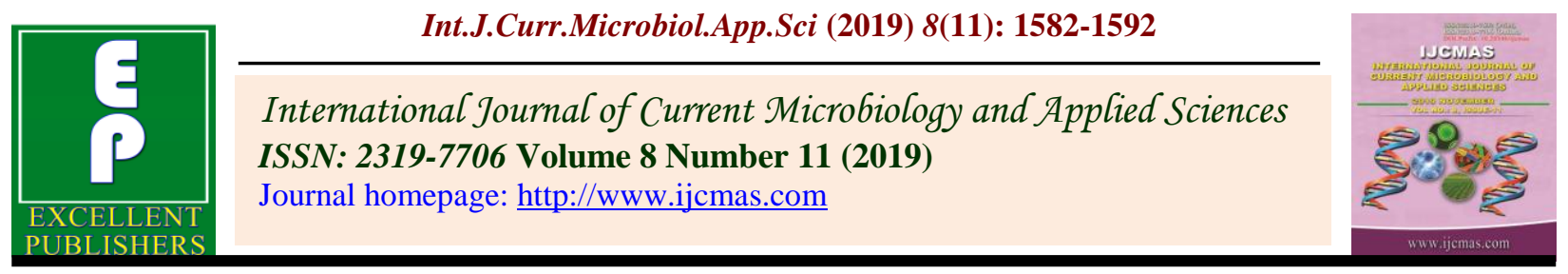

Original Research Article

https://doi.org/10.20546/ijcmas.2019.811.183

\title{
Isolation and Characterization of Coliform Bacteria and Bacteriophages from Ganga River in Northern Himalayan Regions
}

\author{
Ankit Dimri, Chandra Awasthi, Shubhakriti Uniyal, Aarti Nautiyal and K.P. Singh*
}

Department of Bioscience D.B.S (PG) College, Dehradun, Uttarakhand, India

*Corresponding author

\begin{abstract}
A B S T R A C T
Keywords

Coliform

bacteria,

Himalayan

regions

Article Info

Accepted:

12 October 2019

Available Online:

10 November 2019

River Ganga with its source in Himalayas is considered to be the most sacred and holy river in Hinduism. Anthropogenic activities in the Ganga is deteriorating the quality of water and raising a serious question about purity of the water of river Ganga and its suitability to be used for drinking and other purposes. The present study is aimed to check the bacteriological quality of the Ganga water by analyzing the coliform bacteria and Bacteriophages in the Ganga. The sample were processed and analyzed for their quality with respect to various microbiological aspects. Investigation Method used for detection of coliform bacteria is Most Probable Number Technique and Surface plating and detection of bacteriophages are Isolated and characterized by plaque assay method.
\end{abstract}

\section{Introduction}

The water is the container of life and strength. The quality of water is very important to the health. The Ganga is the sacred fluid and an essential element for all the Hindu rites and rituals (Buhtiani et al., 2016). The main river stream of Ganga originates from the Garhwal Himalayan river called Bhagirathi, which joins with Alaknanda (originates nearly) to form Ganga at the craggy canyon carved town of Devprayag. Therefore, the sacred Ganga is a confluence of rivers Bhagirathi and Alaknanda. As the Ganges flows out of the Himalayas, it creates a narrow, rugged canyon. The Ganges River emerges from the Himalayas at the town named Rishikesh where it begins to flow onto the indo-Gangetic plain, Rishikesh is known as the gateway to the Garhwal Himalayas. From here, the Ganga travels to the Haridwar, which is a Hindu pilgrimage Centre. Till Haridwar, the route of Ganga is little southwest, from here it begins to flow southeast through the plains of northern India. Ganga flows southeast through Indian states of UP, Bihar and West Bengal (Ashbolt, 2001). The Ganges passes some of the most popular cities of India including Kanpur, Allahabad, Varanasi, Patna and Kolkata. 
The Ganga is not only a holy river, but also a lifeline of a large population of India, as it covers more than $26 \%$ of the country's area in its basin in the north and drains $25 \%$ of the annual run-off. Fast urbanization and steep demand for water have led to serious problem of water quality degradation (Baghel, 2005). One of the main reasons of the pollution of Ganga River is faecal coli forms bacteria and organic pollution which is due to open defecation and discharge of waste water directly through small drains into the river (Singh, 2010).

The value of coliforms indicating sewage is directly dumped into the river (Sood A. Singh, 2008). Almost all the lodges, hotels and residential building dump their waste water into the Ganges in Rishikesh, Haridwar and other cities situated upstream of Ganga river.

Despite of pollution created by human, the river Ganga supports a wide diversity due to its self-cleaning and regeneration properties. Studies in 1896 by British bacteriologist Ernest Hankin showed the antimicrobial properties of river Ganga against Vibrio cholera, causative agent of cholera which gets destroyed in Ganga water but thrived in tap water. He proposed that a heat labile unknown substance which Passed through fine porcelain filters was responsible for preventing the spread of Cholera epidemic near downstream villages.

After a decade in 1916 Felix d' Herelle, a French Canadian microbiologist proposed that it was virus that parasitized bacteria based on the appearance of small, clear zones in the lawn of bacterial culture and the lysis in liquid culture.

He initially named it as taches, thentaches verges and later plaques. Felix $d$ ' Herelle officially named it as "bacteriophage" that formed from "bacteria" and "phagein" which meansphages "eat" or "devour" bacteria (Sulakvelidze et al., 2001).

Bacteriophage is the prokaryotic viruses that solely infect and/ or destroy the bacteria. Bacteriophage were associated with the special property of river Ganges (Hankin, 1896; D’Herelle, 1917) and it always present in the water and can survive thousands or lakhs of years even without having food (Adams, 1959). The source of the bacteriophage in Ganga is not yet known, right from the Gangotri from where it originates to the Sundarban delta where it merges into sea. Bacterial viruses (Bacteriophage) occupy all those habitats of the world, where bacteria thrive (Mulani, et al., 2015). It has been estimated that for each bacterial cell there are ten bacteriophage particles. Viruses are considered as obligate intracellular parasites requiring a specific host cell for its replication (Guttman et al., 2005) these are selfish replicators that use bacterial genome for their replication.

\section{Materials and Methods}

\section{Sample collection}

The sample was collected onsterile screw capped container from the various sites of Uttarakhand Ghats safely. The various sites are Badarinath, Devprayag, Uttarkashi, Rishikesh \& Haridwar. All the samples are collected from Northen Himalayan Region, Uttarakhand, India (Fig. 1 and Table 1).

\section{Media and reagents}

All the media like Nutrient agar, MacConkey agar, MacConkey broth, Tryptone broth, LB Agar,Citrate agar,MR-VP Medium,Gelatin hydrolysis medium and reagent like Gram stain, indole reagent which are used in this experiment are manufactured by Hi-Media. 


\section{Microbial analysis of water sample}

\section{Most Probable Number (MPN) technique}

The most probable number (MPN) is a statistical method to detect the number of coliform bacteria in a sample, most commonly for water. This test involves a multiple series of Durham fermentation tube and is divided into three parts- the presumptive, confirmed and completed tests (Fig. 2 and Table 2).

\section{Presumptive test}

This test is a screening method to sample water for the presence of coliform organisms. If presumptive test is negative no further test is done.

\section{Procedure}

The tubes containing $10 \mathrm{ml}$ of single strength MacConkey broth (SSMB) and double strength MacConkey broth (DSMB) were prepared. A Durham's tube was placed in each tube in an inverted position. The tubes were labeled according to the amount of water sample to be dispensed into it i.e. $10 \mathrm{ml}, 1 \mathrm{ml}$ and $0.1 \mathrm{ml}$. The water sample was homogenized by shaking the bottle containing the water vigorously several times. $10 \mathrm{ml}$ of the water sample were transferred to each of the 5 DSMB tubes using a $10 \mathrm{ml}$ pipette, with a micropipette, $1 \mathrm{ml}$ and $0.1 \mathrm{ml}$ of the water sample were transferred to batches of $5 \mathrm{ml}$ SSMB tubes and Incubated at $37^{\circ} \mathrm{C}$ for 24 hours and the number of tubes in each set that produced $10 \%$ or more gas with a change in color from purple to yellow was recorded. MPN was determined by referring to the MPN table by "Mackie and McCartney".

\section{Confirmatory test}

Some microorganism other than coliform bacteria also produces acid and gas thus to confirm presence of coliform bacteria, confirmatory test was performed.

\section{Procedure}

A loopful of culture from positive tubes was transferred to a fermentation tube containing brilliant green lactose bile broth tubes were incubated for $48 \pm 3$ hours at $35 \pm 0.5^{\circ} \mathrm{C}$.

Number of tubes that produced gas was recorded.

\section{Completed test}

Since some microorganism show false positive results, so it is desirable to do completed test.

\section{Procedure}

The sample from all positive BGLB tube is streaked onto eosin methylene blue agar and incubated at $37^{\circ} \mathrm{C}$ for 24 hours. Colonies produced greenish metallic sheen is differentiated from non-coliform bacteria.

\section{Isolation and enumeration of bacterial pathogen}

The direct plating procedures were followed for the isolation and enumeration of bacterial pathogen on Nutrient agar medium by the spread plate technique. When the growth was observed the separate colonies was sub cultured on MacConkey agar medium by surface plating. After the observation of growth, the Biochemical tests are used for identification of organisms.

\section{IMViC test}

This is a series of group of four individual tests used to identify coliform bacteria. The four reactions are: Indole test, Methyl-red test, Voges Proskauer test and Citrate test. 


\section{Indole test}

This test demonstrates the ability of certain bacteria to decompose the amino acid tryptophan into metabolic product indole, which accumulates in the medium. Using Kovac's reagent, indole combine with pDimethyl amino benzaldehyde which in acidic $\mathrm{pH}$ produce red-violet compound.

\section{Procedure}

$5 \mathrm{ml}$ media was poured in culture tubes and autoclaved at $121^{\circ} \mathrm{C}$ for $15-20$ minutes for sterilization. Then $5 \mathrm{ml}$ of media were inoculated with pure culture and incubated overnight at $37^{\circ} \mathrm{C}$. To this $0.5 \mathrm{ml}$ of Kovac's reagent were added and observed for color formation. Cherry red color show positive test and original color indicates negative result.

\section{Methyl red test}

Methyl red (MR) test is a biochemical test performed on bacterial species to detect the ability of an organism to produce stable acids end products (mixed acid fermentation) from supplied glucose.

\section{Procedure}

$5 \mathrm{ml}$ media was poured in culture tubes and autoclaved at $121^{\circ} \mathrm{C}$ for $15-20$ minutes for sterilization. Then $5 \mathrm{ml}$ of media were inoculated with pure culture and incubated overnight at $37^{\circ} \mathrm{C}$. To this 5 drops of methyl red indicator were added and observed for color formation. A distinct red color show positive test and distinct yellow color indicates negative result.

\section{Voges proskauer (VP) test}

The Voges proskauer (VP) test is used to determine if an organism produces acetyl methyl carbinol from glucose fermentation. If present, acetyl methyl carbinol is converted to diacetyl in the presence of $\alpha$-Napthtol, strong alkali $(40 \% \mathrm{KOH})$, and atmospheric oxygen. This is indicated by pinkish red color.

\section{Procedure}

$5 \mathrm{ml}$ media was poured in culture tubes and autoclaved at $121^{\circ} \mathrm{C}$ for $15-20$ minutes for sterilization.

Then $5 \mathrm{ml}$ of media were inoculated with pure culture and incubated for $24-48$ hours at $37^{\circ} \mathrm{C}$. To this $0.6 \mathrm{ml}$ of $\alpha$ Napthtol added and observed for color formation. Cherry red color show positive test and original color indicates negative result.

\section{Citrate test}

Citrate agar is used to test an organism's ability to utilize citrate as the carbon source.

\section{Procedure}

Pure culture was streaked on Simmon's Citrate agar with the help of inoculating loop. The slants were incubated for 48 hours at $37^{\circ} \mathrm{C}$. Growth on slants changes the color of slants from green to blue. No color change indicates negative result.

\section{Hanging drop method (motility test)}

Hanging drop preparation is a special type of wet mount (in which a drop of medium containing the organisms is placed on a microscope slide), often is used in dark illumination to observe the motility of bacteria.

\section{Procedure}

Dab Vaseline on cover slip edges using a toothpick then place loopful of culture broth in the Centre of cover slip, turn the concavity 
slide upside down over the cover slip and observe the motility on slide under microscope.

\section{Catalase test}

Catalase is an enzyme, which is produced by microorganism that lives in oxygenated environments to neutralize toxic forms of oxygen neutralizes the bactericidal effects of hydrogen peroxide and protects them.

Anaerobes generally lack the Catalase enzyme. Catalase mediates the breakdown of hydrogen peroxide $\mathrm{H}_{2} \mathrm{O}_{2}$ into oxygen and water. To find out if a particular bacterial isolate is able to produce Catalase enzyme, a small inoculums of bacterial isolate is mixed into hydrogen peroxide solution $(3 \%)$ and is observed for the rapid elaboration of oxygen bubbles.

\section{Bacteriophage isolation and purification}

After isolation of coliform bacteria from Ganga River their respective Bacteriophages were isolated.

\section{Removal of contaminants of water}

$1.5 \mathrm{ml}$ Ganga sample was taken out from each Ganga water sample in Eppendorf tube by the help of micropipette. Sample was treated with $1 \%$ chloroform for 20 minutes then centrifuged at $10,000 \mathrm{rpm}$ for 10 minutes(Seaman P.F, Day M.J, (2007)). After centrifugation the upper part of the water decanted into a new sterile conical tube and was taken out for processing.

\section{Plaque assay for phage concentration}

Plaque is a clear lysed area in a monolayer displaying acytopathic effect. Plaque is formed when a virus infects a cell (Yang et al., 2010).

\section{Procedure of plaque assay}

\section{Enrichment of coliform bacteria}

Species of coliform bacteria was inoculated into $50 \mathrm{ml}$ of nutrient agar medium then incubated overnight at $37^{\circ} \mathrm{C}$.

\section{Amplification of bacterial virus}

Isolated bacteria were inoculated in $5 \mathrm{ml}$ sterile nutrient agar medium for 24 hours at $37^{\circ} \mathrm{C}$. Following day, $5 \mathrm{ml}$ of the preincubated bacterial inoculum, $5 \mathrm{ml}$ of (10X) nutrient broth, $40 \mathrm{ml}$ of Ganga sample was mixed and was incubated for 24 hours at $37^{\circ} \mathrm{C}$.

\section{Bacteriophage isolation and plating}

After incubation, bacteria-bacteriophage culture was centrifuged for 5 minutes at 2000 rpm and supernatant was separated. Then supernatant was filtered, this step removes remaining bacteria. Prepare a series of microfuge tube for making bacteriophage dilution. Distribute $0.5 \mathrm{ml}$ of coliform bacterial species into each of six microfuge tube, labeled 1-6. Incubate at $37^{\circ} \mathrm{C}$ for 10 minutes to allow the phage to adsorb (attach) to the bacteria. The cell phage mix is prepared. In the meantime, label six warm, dry, nutrient agar plates 1-6 (one for each infection). Write on the bottom plate along the late edge. Keep the plates in the $37^{\circ} \mathrm{C}$ incubator until used. Add the content of cell-phage tube 1 to a vial containing $3 \mathrm{ml}$ of top agarose (molten, at $45^{\circ} \mathrm{C}$ ). Quickly cap the tube, and mix it by gently inverting it three times. Quickly pour the mixture into warmed plate 1. Slightly tip the plate to spread the top agarose. Push the plate aside, but do not pick it up until agarose solidify. Repeat this step for each of the remaining 5 samples, 2-6 then allow the plates to cool without being disturbed for approximately 10 minutes after the top 
agarose has solidified, incubate the plates, inverted, at $37^{\circ} \mathrm{C}$ for 24 hours. Plaques were observed on the agar medium plates (Ellis and Winters, 1969).

\section{Results and Discussion}

\section{Most Probable Number (MPN) of coli forms}

Coli forms count performed by multiple normal tubes to determine the most probable number (MPN) is commonly used as indicator of portability of water.

It gives us statistical estimate of coli forms population and measured the extent of coli forms in $100 \mathrm{ml}$ water. Coli forms produce gas and acid hence the production of gas in Durham tube, constituted positive test (Vass, 2010).

It is generally believed that more is the MPN of coli forms, higher is the extent of pollution in a given sample indicating heavy bacterial load and contamination.

The main source of organic burden of sewage in most communities is human body waste or faeces and microorganisms themselves are a part of human faeces.

When water sample is tested, it is not possible to identify all water borne pathogens. The solution is to look for indicator organism i.e. coli forms group of bacteria which contain $E$. coli, Proteus spp, Klebsiella spp. During the study plates were incubated at $37^{\circ} \mathrm{C}$ and $44.5^{\circ} \mathrm{C}$.

All the water samples collected during the study some are positive and some are negative with respect to the coli forms occurrence well above the permissible limits, though the counts were variable. It is generally believed that more is the MPN of coli forms, higher is the extent of pollution in a given sample.

\section{Bacterial characteristics on media}

\section{On nutrient agar media}

White, creamy and fairly circular colonies were observed on Nutrient agar medium plate and shows swarming in the subculture as seen in figure 3.

\section{On MacConkey agar}

Lactose and non-lactose fermenting colonies was observed. E. coli colonies were observed as dark pink, dry on MacConkey while Klebsiella were observed as large shiny, and dark pink in color. Proteus was observed as pale, colorless and translucent colonies as shown in figure 4.

\section{Morphological studies}

\section{Gram's staining}

Gram staining reactions were studies with all the isolated culture to determine their morphology. Some isolates were gram negative bacilli while some were gram negative cocci. Some isolates are gram positive cocci, shown in the figure 5 .

\section{Biochemical characterization of isolates from various Ganga water sample}

The sample were spread on nutrient and MacConkey medium according to the test required and the colonies that appeared after 24-48 hours were picked up based on their characterization and Biochemical test like: IMViC, catalase and motility test are performed.

\section{Indole test}

The isolates were screened for indole test. Red colored ring is observed in the tryptone broth containing bacterial isolates indicating presence of E. coli (Fig. 6 and Table 3). 


\section{Methyl red test}

The isolates were screened for $\mathrm{M}-\mathrm{R}$ test. A distinct red color is observed in the M-R media of bacteria isolates indicating presence of E. coli and Proteus.

\section{Voges Proskauer test}

The isolates were screened for VP test. A cherry red color change is observed in the isolates containing VP media indicating presence of Klebsiella and Proteus.

\section{Citrate test}

The isolates were screened for citrate test. Green color is observed in the citrate media containing bacterial isolates indicating presence of Klebsiella and Proteus (Fig. 7).

\section{Motility test}

The isolates were screened for motility test. Brownian movement is shown by bacteria when observed under microscope.

\section{Catalase test}

All isolates were screened for Catalase test. Bubbles are produced which indicates breakdown of hydrogen peroxide by bacteria, indicating presence of E. coli and Klebsiella as shown in figure 8 .

\section{Biochemical characterization of bacterial isolates}

\section{Isolation of baceteriophage}

All the plates showed positive for the isolation of bacteriophage, round, clear and transparent plaques are observed in the plates, indicating that the samples collected from different ganga river contained bacteriophage that were infectious against Coliform bacteria (Vitaliano et al., 2007). The phages produced clear plaques with well-defined edges in bacterial lawn, showing that the isolated phages have lytic effect against coliform bacteria (Fig. 9).

Natural water bodies are extensively polluted with the life -threatening biological and toxic organic and inorganic pollutants. In India 70\% surface water resources have already been polluted.

The current study has been taken up to isolates the bacteriophage of coliform bacteria from river Ganga, due to its holiness large number of people as well as pilgrim use the Ganga water for drinking and bathing purposes. The project aims to check the bacteriophage presence in Ganga River as increase in pollution of Ganga River directly affects the quantity of Bacteriophages as these are the viral indicators of coliform bacteria. The Ganga sample were processed and analyzed for their quality with respect to coliform bacteria and then its bacteriophages are isolated.

The results obtained from the microbial analysis of the Ganga River water signified the occurrences of the bacterial pathogens at the sites indicated fecal contamination in the holy river. The high load of coliform bacteria in the river sites is possible, as the human population in northern region has grown considerably due to presence of Ganga River, due to which the holy river became polluted. Bacteriophages present in River Ganga kill or infect bacteria which gave Ganga River its bactericidal affect and help Ganga River possess its medicinal qualities.

To isolates coliform bacteria and their bacteriophages various sample were collected from different sites of Northern Himalayas. These sample were processed and analyzed to detect coliform bacteria by microbial and biochemical methods and then plaque forming methods and general enrichment methods are employed for detection of bacteriophage of these isolated coliform bacteria. 
Table.1 Sampling sites and date of collection

\begin{tabular}{|c|c|c|c|}
\hline S.no & $\begin{array}{c}\text { sampling } \\
\text { code }\end{array}$ & Sampling Sites & Date of Collection \\
\hline $\mathbf{1 .}$ & G1 & Badarinath & 17.04 .19 \\
\hline $\mathbf{2 .}$ & G2 & Devprayag & 17.04 .19 \\
\hline $\mathbf{3 .}$ & G3 & Uttarkashi & 20.05 .19 \\
\hline $\mathbf{4 .}$ & G4 & Rishikesh & 17.05 .19 \\
\hline $\mathbf{5 .}$ & G5 & Haridwar & 22.04 .19 \\
\hline
\end{tabular}

Table.2 MPN value/100ml

\begin{tabular}{|c|c|c|c|}
\hline S.No & Sample No. & $\begin{array}{c}\text { Date of } \\
\text { Processing }\end{array}$ & MPN Value/100ml \\
\hline $\mathbf{1 .}$ & G1 & 19.04 .19 & 8 \\
\hline $\mathbf{2 .}$ & G2 & 19.04 .19 & 12 \\
\hline $\mathbf{3 .}$ & G3 & 22.05 .19 & 17 \\
\hline $\mathbf{4 .}$ & G4 & 19.05 .19 & 70 \\
\hline $\mathbf{5 .}$ & G5 & 24.04 .19 & 220 \\
\hline
\end{tabular}

(Mackie \& McCartney, Practical Medical Microbiology, $14^{\text {th }}$ edition)

Table.3 Biochemical characterization of obtained isolates

\begin{tabular}{|c|c|c|c|c|c|c|c|}
\hline $\begin{array}{c}\text { Bacterial } \\
\text { isolates }\end{array}$ & Gram stain & Indole Test & MR Test & $\begin{array}{c}\text { VP } \\
\text { Test }\end{array}$ & $\begin{array}{c}\text { Citrate } \\
\text { Test }\end{array}$ & $\begin{array}{c}\text { Motility } \\
\text { Test }\end{array}$ & $\begin{array}{c}\text { Catalase } \\
\text { Test }\end{array}$ \\
\hline E.coli & -ve & $+v e$ & $+v e$ & $-v e$ & $-v e$ & $+v e$ & $-v e$ \\
\hline Klebsiella & $-v e$ & $-v e$ & $-v e$ & $+v e$ & $+v e$ & $-v e$ & $+v e$ \\
\hline Proteus & -ve & $+v e$ & $+v e$ & $-v e$ & $+v e$ & $-v e$ & $-v e$ \\
\hline
\end{tabular}

Fig.1 Sample collection from various sites

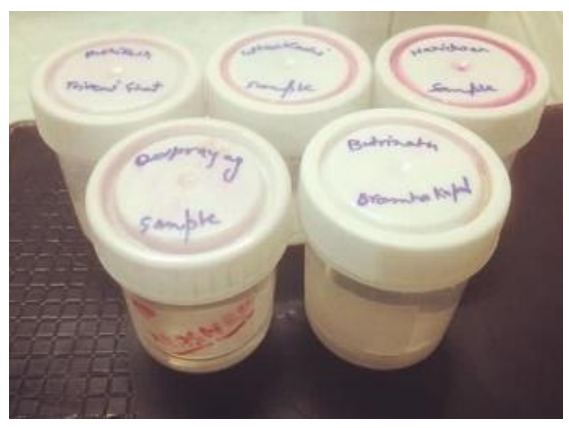


Fig.2 MPN for coliform detection

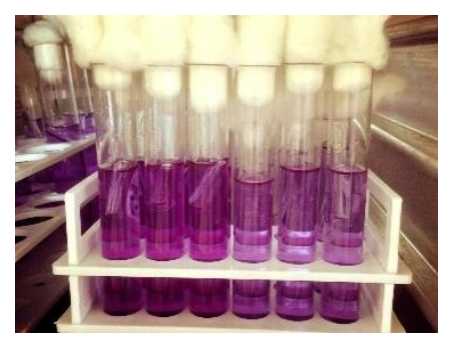

Fig.3 Isolation of bacteria in nutrient agar medium
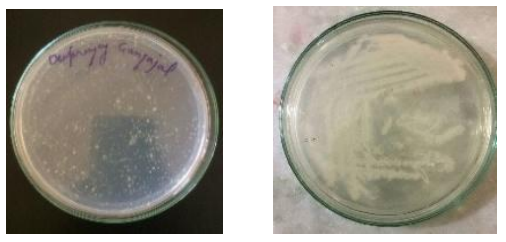

Fig.4 Isolation of bacteria in MacConkey agar medium
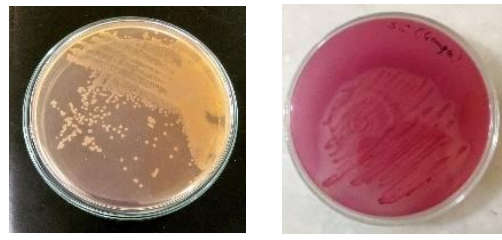

Fig.5 Gram staining of isolates

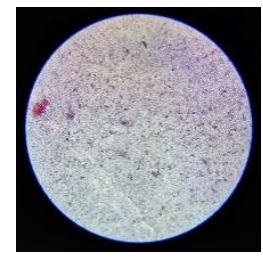

Fig.6 Indole test

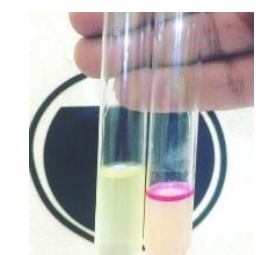


Fig.7 Citrate utilization test

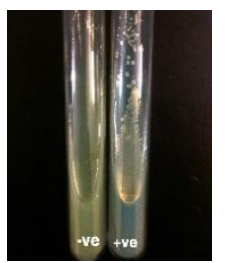

Fig.8 Catalase test

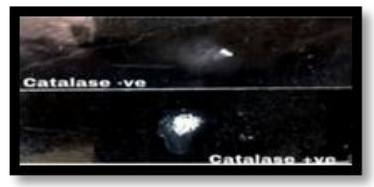

Fig.9 Isolation of bacteriophage from plaque assay method
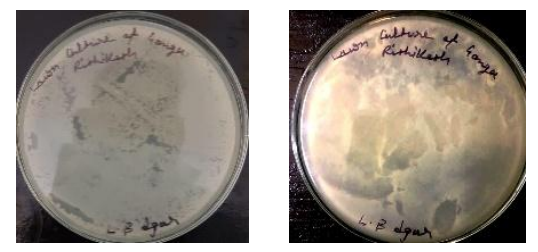

These viruses help in cleaning of the holy River by eradicate the coliform bacteria. Other than that Bacteriophages are the alternative to antibiotics resistant bacteria as the evolution of pathogenic bacteria against commercially available antimicrobial agents has become a critical problem in modern era. Phage therapy could be used as potential alternative to antibiotics.

Despite unabated disposal of waste, river Ganga finds its own way to survive with its antimicrobial attributes due to the presence of bacteriophages. These Bacteriophages are viruses that infect bacteria that can be used as a potential tool for cleaning microbial based pollution from holy River Ganga as these viruses' combat bacteria without a harmful effect on the human body. In Ganga River, Bacteriophages were detected to be approximately 3 times more in proportion and the species of Bacteriophages which are present in river are unique giving the river its holy property. Bacteriophages are protein - based biological agents (viruses) can potentially interact with the body's immune system. It can actively replicate and evolve after administration. Its higher replication rate has been also beneficial at the commercial production of phage. Bacteriophages have several characteristics that make them potential therapeutic agents i.e., they are highly specific and very effective in lysing targeted pathogenic bacteria, safe, and have ability to rapid modification to combat emergence of newly arising bacterial threats.

\section{References}

Adams M.H. (1959). Discovery of Bacteriophage and method of study of bacterial viruses. Bacteriophage vol42, Interscience Publication, New York.

Ashbolt NJ, Grabow wok, Snozzi M. (2001). Indicators of microbial water quality. In: water quality guidelines, standards 
and health. IWA publishing, London, UK.

Baghel, V.S., Gopal K., Diwedi, S., Tripathi, R.D. (2005). Bacterial indicators of faecal contamination of theGangetic river system right its source.

Buhtiani, R; Khanna, D.R., Kulkarni, D.B., and Ruhela, M. (2016). Assessment of Ganges River ecosystem at Haridwar, Uttarakhand, India with reference to water quality indices. Appl water Sci.

D'Herelles, F. (1917). Sur un microbe invisible Anatagoniste des bacillus dysenteriques.

Ellis C.B, Winters A.L. (1969). Isolation of potential MS2 Bacteriophage strain. Biological science.

Guttman, B., Raya, and Kutter, E. 2005. Basic phage biology. In: Kutter, E, and Sulakvelidze, A. Bacteriophage; Biology and application. Florida: CRC Press.

Hankin, E.H. (1896). Laction bactericide des eaux de la Jumna et du Gange sur le vibrion du cholera. Ann Inst a Pasteur.

Mackie \& McCartney, Practical Medical Microbiology, $14^{\text {th }}$ Edition.

Mulani, M. S, Azhar, S, Azharuddin, S, Tembe, S (2015). Harnessing the power of Bacteriophage for pathogen reduction in waste water. Microbial applied science.

Singh K. (2013). Physico-chemical investigation on the pollution potential of River Ganga water at Mirzapur, Uttar Pradesh, India. Ind J Res.

Seaman, P. F. and Day, M. J. (2007). Isolation $\&$ Characterization of a Bacteriophage with an unusually large genome from the great salt plains. National Wildlife refuge, Oklahoma, U.S.A. FEMS Microbiology Ecology

Sood, A., Singh, K.D., Pandey, P. and Sharma, S. (2008). Assessment of bacterial indicators and physicochemical parameters to investigate pollution status of Gangetic river system of Uttarakhand (India). Ecological indicators.

Sulakvelidze, A. and Kutter, E. (2005). Bacteriophage therapy in humans. In bacteriophage: Biology and applications. CRC Press.

Vass K.K, Mondal S.K, Samanta SS, Suresh VR, Kthika PK (2010). The environment and fishery status of River Ganges. Aquat Ecosyst Health Management.

Vitaliano, J, Fromm, S, Packer, D, Reid, R and Pikanowki, R. (2007), Recovery of benthic macrophona from sewage sludge disposal in the New York bight. Marine ecology progress series.

Yang, H, Liang, L, Lin, S, and Gia, S. (2010). Isolation \& Characterization of a virulent Bacteriophage AB1 of Acinetobecter baumannii.

\section{How to cite this article:}

Ankit Dimri, Chandra Awasthi, Shubhakriti Uniyal, Aarti Nautiyal and Singh, K.P. 2019. Isolation and Characterization of Coliform Bacteria and Bacteriophages from Ganga River in Northern Himalayan Regions. Int.J.Curr.Microbiol.App.Sci. 8(11): 1582-1592. doi: https://doi.org/10.20546/ijcmas.2019.811.183 